\title{
Money Supply as a Conduit of the Consumption in the Saudi Economy: A Co-integration Approach
}

\author{
Abdulaziz Hamad Algaeed \\ Department of Economics, College of Economics and Administrative Sciences, Imam Mohamed Bin Saud Islamic University, Riyadh, Saudi \\ Arabia
}

\section{Email address:}

ibngaeed@outlook.com

\section{To cite this article:}

Abdulaziz Hamad Algaeed. Money Supply as a Conduit of the Consumption in the Saudi Economy: A Co-integration Approach. International Journal of Economics, Finance and Management Sciences. Vol. 4, No. 5, 2016, pp. 269-274. doi: $10.11648 /$ j.ijefm.20160405.16

Received: August 30, 2016; Accepted: September 8, 2016; Published: September 28, 2016

\begin{abstract}
This paper focuses on exploring the conduit through which wealth, aggregated by broad money supply, affects the real private consumption in the Saudi economy. In other words, the relationship between money supply (proxy of wealth), among other variables, and the real private consumption function. This study covers the period of 1985-2014. The short and long-run relationships are estimated using co-integration techniques. The results support the existence of positive effects of wealth over private consumption. Also, consumption is affected negatively by changes in prices in the long-run.
\end{abstract}

Keywords: Consumption, Saudi Arabia, Co-integration Analysis, Wealth, Inflation

\section{Introduction}

Not recently, there has been a great deal of literature that deals with the role of money in consumption function as an explanatory factor of the behavior of the consumption function. The aim of such inclusion is to capture the real balance effect. However, the existence of the money supply in the consumption function may give some insight especially of less developed countries (LDCs, hereafter). Given the characteristics of LDCs, Saudi Arabia reflects an example that should be examined and tested. Saudi Arabia has specific features similar to those of less developed countries, LDCs: dependence on one exhaustible resource, i.e. oil, great participation by the public sector in economic activities, limited integration between the dominant foreign exchange earner (the oil sector) and the rest of the economy. The quadrupling of oil prices which started 1973/74 has benefitted the economy by providing financial resources for investment and to further economic growth and development. The oil windfall also influenced private consumption in a positive manner. For example, private consumption constituted 53 percent out of total expenditure on GDP in 1985 to about 32 percent of total expenditures on GDP in 2014. (Figure 1).
The purpose of this paper is to review and examine empirically the role of money in the private consumption in Saudi Arabia. The co-integration method will be applied. Algahtani, and Alhiyari [3], argue that at least for Saudi Arabia, the money supply M1, was a good measure for wealth and helps to explain the behavior of the private consumption. These authors concluded remarkably that money supply in Saudi Arabia had positively affected the private consumption, contrary to the findings for Iran by Mehdizadeh [15].

The broad hypothesis being tested is that, the inclusion of the money supply among other independent variables, proxy for wealth, in the private consumption function for the Saudi economy spanning the time period from 1985-2014, does a good job in explaining the behavior of real private consumption. It is likely that inflation will exert an influence on private consumption through the effect on real cash balances. Therefore, in order to capture the real effect of the wealth on private consumption, one considers the wealth variable with other independent and relevant variables, such as consumer price index, CPI. The organization of this paper as follows. Section 1 an introduction. Section 2 develops the theory of the macro consumption model. Section 3 presents the statistical results and their discussion for the real private consumption functions with different measurements, and 
section 4 presents a summary of the results and their implications.

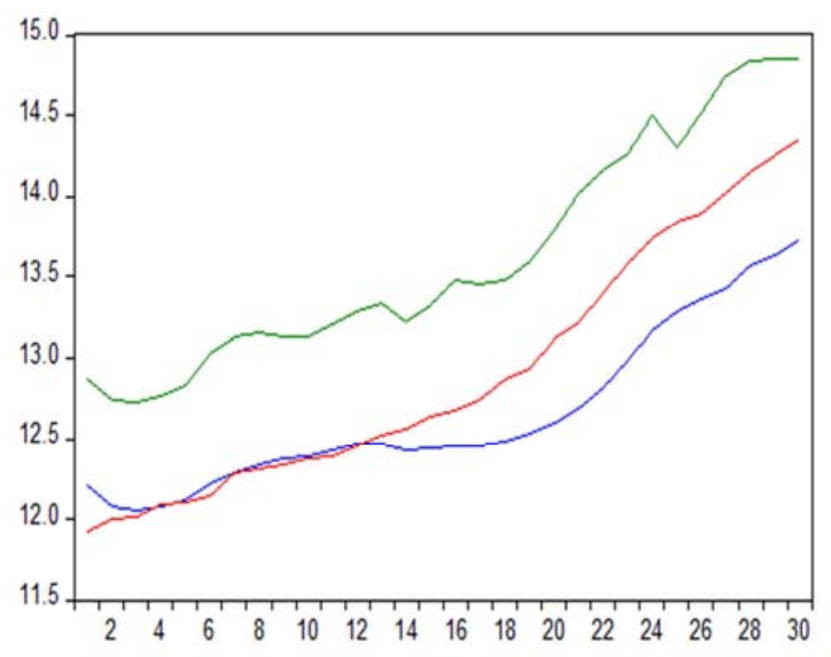

Figure 1. log privet consumption(blue), log national income(green) and log money supply(red).

\section{The Theoretical Macro Model}

As time passes, the accumulation of wealth involves a considerable macroeconomic adjustment on the aggregate level, such as consumption. Keynesian theory explains the consumer behavior on the premise that consumption depends on income and the interest rates. The assumption of this theory is that, the spending unit is not highly responsive to change in the rate of interest over the economically meaningful range, and that its behavior is especially inelastic at the lower end of the range [16]. Therefore, the main conclusion of the Keynesian macro theory is that, current income is the main determinant of the level of the current consumption expenditure and that the marginal propensity to consume out of income is less than one. "However, there are factors affecting personal consumption besides disposable income, such that taxes and expectations of the relation between present and future income [16]".

Friedman's permanent income hypothesis stresses the constant proportional relationship between personal consumption and permanent income. Observed income can be broken into permanent and transitory components. Moreover, this theory is criticized on the grounds that at least one third of the windfall is consumed. Bodkin [5], points out that the consumption of the windfall is between 0.7 and 0.9 . Although permanent income and life-cycle hypotheses tried to reconcile the differences between long and short-run consumption, they stressed the importance of wealth as a factor that influences consumption. Despite the potential important effects of the interest rate as an explanatory variable in the consumption function, numerous studies tend to neglect it in the case of LDCs due to the lack of serious interest rate data.

Lagged income as a determinant of consumption function is discussed extensively in the literature, with different models forwarded to justify its inclusion in the model. These models include the permanent income and life-cycle hypotheses. Economists argue that the purpose of inclusion of the lagged income variable is to represent the permanent income if the time period is too short, to allow for complete adjustment of consumption to the new level of income to occur. Needless to say, the period over which one measures the observations needs to be long enough to allow for complete adjustment [4]. Using the money market equilibrium condition, where $\mathrm{Y}$ is income and $\mathrm{R}$ is the rate of interest, the actual nominal quantity of money can be expressed as:

$$
\mathrm{M}_{\mathrm{t}}=\mathrm{P} . \mathrm{L}(\mathrm{Y}, \mathrm{R})
$$

Assuming a specific functional form and taking log, we have:

$$
\mathrm{Ln} \mathrm{Mt}=\ln \mathrm{P}+\alpha \ln \mathrm{y}+\gamma \ln \mathrm{R}
$$

A rise in price will not increase the demand for money in real term because the actual nominal money rises by the same proportion.

Following the standard literature as a starting point, the private consumption function is specified as follows:

$$
\mathrm{C}_{\mathrm{t}}=\mathrm{g}\left(\mathrm{Y}_{\mathrm{t}}, \mathrm{M}_{\mathrm{t}}\right)
$$

We can rewrite it in the following form:

$$
\mathrm{C}_{\mathrm{t}}=\mathrm{g}_{0}+\mathrm{g}_{1} \mathrm{Y}_{\mathrm{t}}+\mathrm{g}_{2} \mathrm{M}_{\mathrm{t}}
$$

Where $g_{1}$ and $g_{2}$ are the marginal propensities out of income and aggregate money supply (there are no government bonds). The total change in consumption consists of two parts: the direct change in consumption as income changes, and the change in consumption due to the change in wealth represented by $\mathrm{M}_{\mathrm{t}}$.

Liquid assets symbolize the portfolio balance or wealth effect. Households need a certain liquid asset, and if the real value of liquid assets diverges from the desired level, saving will tend to adjust, and hence, consumption. In this case, liquid assets serve as a buffer stock for households. The proxy for the liquid assets $\left(\mathrm{M}_{\mathrm{t}}\right)$ is a broad definition of the money supply $\left(\mathrm{M}_{3}\right)$. Furthermore, following the standard money demand process, and following [4], [1]. I assume that the adjustment of the actual to the desired money supply is such that:

$$
\mathrm{M}_{\mathrm{t}}=\varnothing \mathrm{M}_{\mathrm{t}}^{*}+(1-\varnothing) \mathrm{M}_{\mathrm{t}-1}
$$

Where $\mathrm{M}_{\mathrm{t}}{ }^{*}$ is the desired money supply, and $\varnothing$ represents the adjustment coefficient which takes a value between zero and one. A further assumption is that, the desired money supply depends on real income and the change in the price level. Assuming a specific functional form, such that:

$$
\mathrm{Mt}^{*}=\mathrm{b}_{0}+\mathrm{b}_{1} \mathrm{Y}_{\mathrm{t}}+\mathrm{b}_{2} \mathrm{P}_{\mathrm{t}}
$$

Substitution yields:

$$
\mathrm{M}_{\mathrm{t}}=\varnothing \mathrm{b}_{0}+\varnothing \mathrm{b}_{1} \mathrm{Y}_{\mathrm{t}}+\varnothing \mathrm{b}_{2} \mathrm{P}_{\mathrm{t}}+(1-\varnothing) \mathrm{M}_{\mathrm{t}-1}
$$


Or:

$$
M t=f_{0}+f_{1} Y_{t}+f_{2} P_{t}+f_{3} M_{t-1}
$$

Where:

$\mathrm{f}_{0}=\varnothing \mathrm{b}_{0}$

$\mathrm{f}_{1}=\varnothing \mathrm{b}_{1}$

$\mathrm{f}_{2}=\varnothing \mathrm{b}_{2}$

$\mathrm{f}_{3}=(1-\varnothing)$

Inflation is expected to exert two separate influences on saving. It encourages the holding of real assets rather than nominal ones. At the same time, inflation creates a feeling of uncertainty and pessimism about the future which encourages saving [10]. The rationale for including CPI is, to reflect the erosion of the real value of the consumer's total wealth [10]. Moreover, the coherent justification for the inclusion of CPI is that, expectations about increases in price will cause a fear of erosion of the real value of the financial assets shifting the demand for real assets at the expense of financial assets. So, the impact of future inflation on consumption and saving will depend largely on the behavior of households and on the degree of indexation of real income and interest rate. [14]. Another explanation is that, inflation may change the distribution of income among households and affect saving behavior and hence, consumption [10]. Others, suggest that, the price level will reflect the wealth effect. Their main reason is that; price level exerts influence on consumption through the reduction of real balances. If the accumulation of the real assets is the predominant motivation, one would expect a negative effect of expected inflation on consumption. Howard termed it as flight from currency [10].

The ad hoc specification form of the private consumption function, is the following:

$$
\mathrm{C}_{\mathrm{p}}=\mathrm{g}_{0}+\mathrm{g}_{1} \mathrm{Y}_{\mathrm{t}}+\mathrm{g}_{2} \mathrm{f}_{0}+\mathrm{g}_{2} \mathrm{f}_{1} \mathrm{Y}_{\mathrm{t}}+\mathrm{g}_{2} \mathrm{f}_{2} \mathrm{P}_{\mathrm{t}}+\mathrm{g}_{2} \mathrm{f}_{3} \mathrm{M}_{\mathrm{t}-1}+\mathrm{U}_{\mathrm{t}}
$$

Rearranging terms yields the final form:

$$
\mathrm{C}_{\mathrm{p}}=\left(\mathrm{g}_{0}+\mathrm{g}_{2} \mathrm{f}_{0}\right)+\left(\mathrm{g}_{1}+\mathrm{g}_{2} \mathrm{f}_{1}\right) \mathrm{Y}_{\mathrm{t}}+\left(\mathrm{g}_{2} \mathrm{f}_{2}\right) \mathrm{P}_{\mathrm{t}}+\left(\mathrm{g}_{2} \mathrm{f}_{3}\right) \mathrm{M}_{\mathrm{t}-1}+\mathrm{U}_{\mathrm{t}}
$$

\section{The Empirical Results}

In order to see the effect of money supply (Proxy for wealth) on the private consumption function, one considers the real national income lagged one year. The rationale behind using lagged real national income is, the existence of time lag between receiving income and spending it. However, the use of consumer price index (CPI) is to reflect the power of inflation that exerted on private consumption through the decline of real income. Due to the stationarity of the economic variables, it is necessary to perform the unit root test and error-correction methodology (ECM). Therefore, the determination of the order of the integration of each variable used in this study, tells us whether exists stationarity or the variables include a stochastic trend, i. e., how many times each variable needs to be differenced in order to reach stationarity. Although, time series literature suggests that variables are stationary, but if nonstationary, spurious results are likely to appear. To overcome nonstationarity problem, first differenced I(1) variables are applied [8].

\subsection{Unit Root Test}

Due to the stationarity of time series, it is of interest to perform the unit root tests and the error-correcting methodology. To achieve this task, Augmented Dickey-Fuller (1987), (ADF), and Phillips and Perron (PP) (1990) tests are executed. Results are reported in table 1. Both tests showed that all variables are stationary at the difference in the ADF test. Whereas, lagged money supply is stationary at level only. Furthermore, all considered variables are integrated of order one or I(1). Although, KPSS test is being used, its interesting results were not reported.

Using Engle and Granger, [6], a single equation method is built on the assumption that all variables in the model have to be integrated of the same order. Thus, all variables in the model are integrated of order one, I(1). To do so, long-run relationships between $Y_{t}$ and $X_{t}$ are of the form:

$$
Y_{t}=\beta_{0}+\beta_{1} X_{t}+e_{t}
$$

Utilizing OLS the above equation is estimated and the residual saved and tested for stationary. Moreover, if residual $e_{t}$ is stationary, then $Y_{t}$ and $X_{t}$ are co-integrated and have long-run relationships. Applying ECM, all short run variables are significant at 5 percent level. The residual $\left(\mathrm{U}_{\mathrm{t}-1}\right)$ has been tested for stationarity. The results came up significant at 5 percent level, indicating long-run relationships between real private consumption (RPC) and the rest of the independent variables in this analysis, table 3.

Table 1. Augmented Dickey-Fuller and Phillips-Perron tests.

\begin{tabular}{lllll}
\hline & Augmented-Dickey Fuller (ADF) & & \multicolumn{2}{l}{ Phillips Prron(PP) } \\
\hline & LEVEL & $1^{\text {st }}$ DIFFERENCE & LEVEL & 1stDIFFERENCE \\
\hline series & Intercept & Intercept & Intercept & Intercept \\
RCP & $3.7343^{*}$ & $3.0746^{*}$ & $3.0801^{*}$ & $3.0715^{* *}$ \\
Lagged RMt & $4.41536^{*}$ & $2.7112^{* *}$ & $3.465^{*}$ & 2.0816 \\
Lagged RNI & 0.78768 & $4.9787^{*}$ & 1.385 & $4.980^{*}$ \\
CPI & 0.53653 & $2.6761^{* *}$ & 2.0664 & 2.498 \\
\hline
\end{tabular}

$(*)$, and $(* *)$ are statistically significant at $5 \%$ and $10 \%$ level respectively. 
Table 2. Trace test: indicates 4 co-integrating equations at the $0.05 \%$ level.

\begin{tabular}{llll}
\hline Hypothesized No of CE(s) & Eigenvalues & Trace Statistics & 0.05 Critical Values \\
\hline None* & 0.7811 & 76.8485 & 47.8561 \\
At most 1* & 0.5433 & 38.8276 & 29.7971 \\
At most 2* & 0.3871 & 19.2338 & 15.4947 \\
At most 3* & 0.2441 & 6.9962 & 0.0000 \\
\hline
\end{tabular}

(*) denotes rejection of the hypothesis at the $0.05 \%$ level.

(**) Mackinnon-Haug-Michelis (1999) p-values.

Table 3. Estimates of the real consumption function coefficients with ECT $(N=30)$.

\begin{tabular}{ll}
\hline & Dependent Variable: \\
\hline \multirow{2}{*}{ RCPstant } & 0.2712 \\
& $(0.0097)$ \\
RM $_{\mathrm{t}}(-1)$ & 0.1819 \\
& $(2.9033)^{*}$ \\
$\mathrm{RNI}(-1)$ & 0.05276 \\
& $(4.1943)^{*}$ \\
$\mathrm{CPI}$ & 43.8188 \\
& $(3.6707)^{*}$ \\
$\mathrm{U}(-1)$ & -0.973 \\
$\mathrm{R}^{2}$ & $(-3.7674)^{*}$ \\
F statistics & 0.82171 \\
D-W statistics & 26.5006 \\
\hline
\end{tabular}

Notes: t-statistics are in parentheses. The *asterisk denotes significance at $0.05 \%$ level.

Table 4. VAR estimates of the real consumption function coefficients. ( $N=30)$.

\begin{tabular}{llllll}
\hline & \multicolumn{5}{c}{ Dependent Variable RCP } \\
\hline & Coefficient & t-statistics & & Coefficient & t-statistics \\
\hline ECT & 0.0078 & $(0.0339)$ & $\mathrm{D}(\mathrm{RNI}(-2))$ & 0.0618 & $(0.7176)$ \\
$\mathrm{D}(\mathrm{RCP}(-1))$ & -0.1210 & $(-0.333)$ & $\mathrm{D}(\mathrm{RNI}(-3))$ & -0.04399 & $(-0.7387)$ \\
D(RCP(-2)) & -0.726 & $(-0.6077)$ & $\mathrm{D}(\mathrm{CPI}(-1))$ & 38.880 & $(2.8283)^{*}$ \\
D(RMT(-2)) & 0.3176 & $(2.5352)^{*}$ & $\mathrm{D}(\mathrm{CPI}(-2))$ & -19.469 & $(-0.9102)$ \\
D(RMT(-3)) & 0.2107 & $(0.8133)$ & $\mathrm{C}$ & 14.6044 & $(1.4022)$ \\
$\mathrm{R}^{2} 0.695$ & & & & & \\
F 4.049 & & & & & \\
\hline
\end{tabular}

Notes: t-statistics are in parentheses. The *asterisk denotes significance at $0.05 \%$ level.

\subsection{Co-integration Methodology}

Stationarity tests are carried out using ADF and PP. All variables in the model are not stationary. However, they became stationary after first difference. From table 2, trace test indicates the existence of 4 co-integrating equations at the 5 percent level. So, null hypothesis of no co-integration is rejected by trace test. Maximum eigen statistics indicates the existence of a 1 co-integrating equation at the 5 percent level. Thus, null hypothesis of no co-integration is rejected too. Furthermore, Johansen test confirms the rejection of the null hypothesis of no co-integration between RCP and the rest of the independent variables, RNI, RMt-1 and CPI.

\subsection{The Results Discussion}

The model results presented in tables 3 and 4 . It shows that real private consumption is extremely influenced by real aggregate money supply, real income, and CPI. All variables coefficients are significant at 5 percent level. The short-run results support the findings of Algahtani and Alhayari. [3].
Their estimates confirm that the wealth variable plays a major role in determining private consumption in Saudi Arabia. Furthermore, adding the price level to the equation resulted in an improved understanding of the behavior of the wealth variable. The long-run influence of wealth (lagged one period) or long run marginal propensity to consume out of wealth is about 18 percent, while real income (lagged one period) is about 5 percent. The sign of inflation ought to be negative, in order to justify the argument that inflation exerts influence on consumption through reduction of real balances $(\mathrm{M} / \mathrm{P})$. However, the coefficient is positive and significant at 5 percent level. We observed strong long run relationship between private consumption and the broad money supply. The ECT (-1) coefficient shows the percentage in which disequilibrium in the short run be adjusted to its long run equilibria. The more ECM (-1) coefficient, the longer run adjustment. The estimates indicate that the error correction term has a negative sign and significant at 5 percent level. This finding shows that, error correcting term, corrects the disequilibrium of the system at the rate of 97 percent annually. In other words, in each period the adjustment rate 
of marginal consumption expenditure of private consumption to its long run relation is about 97 percent. Vector error correction estimates which reported in table 4, shows that the coefficient of the co-integrated model, or the error correction term is positive and is not significant at any level. So, there exists no long-run causality running from the independent variables of the model towards real private consumption, RCP. The long-run negative sign of the CPI, indicates that Saudis reduce their consumption once they realize that the price level has risen. In order to avoid the loss in real wealth which is in the form of financial assets, consumption will be reduced and the demand for real assets will go up. Another possible justification for this result, Saudis are hedging against inflation by abstaining from current consumption and accumulating wealth in the form of real assets, such as gold and lands. The private consumption function could be adversely affected by inflation. Thus, as liquid assets decrease, private consumption decreases. Further tests have been done to assure the goodness of fit. The model showed no serial correlations, nor heteroscedasticity. The residuals are normally distributed.

\section{Conclusion and Policy Implications}

This paper has sought to investigate the role of broad money supply on real private consumption function in a major oil producing country, Saudi Arabia using real factors, rather than nominal ones. The data were in millions of Saudi Riyals (National currency), and in nominal values. To better understand the role of broad money supply as a conduit of the real private consumption, work has been done to develop and estimate an ad hoc macro econometric model. Real income and consumer price index have been added and tested. The series covered the period of 1985-2014, were integrated in order to evaluate long-run relationships between real private consumption and the rest of independent variables. The above analysis revealed that, the use of broad money supply variable, i.e. $\mathrm{M}_{3}$, as a proxy for wealth, is meaningful even if it is used with other relevant variables. It is worthwhile to note that, our findings support the hypothesis that inflation does affect the consumption. [7], [14]. A rise in inflation will cause a reduction in financial assets leading to a reduction in the private consumption in the long-run. Moreover, consumers adjust their consumption in the long run once they correct their expectations. Immense government expenditure, which is transmitted into the stream of money supply should be watched out so as to maintain stable prices, especially if we want to keep the economy on track.

\section{Acknowledgment}

I would like to express my gratitude to the financial support by the Sheikh Al-Fouzan Saudi Macroeconomic Forecasting Chair (SMF Chair), at Imam University. Riyadh, Saudi Arabia. Special thanks to the director of the chair DR. Khalid Almeshal for his encouragement and support.

\section{References}

[1] Aghevli, B., Sassanpour, C. (1982). Prices, Output and Trade Balance in Iran. World Development. Vol. 10. No 9. Pp. 791-800.

[2] Asif, R. (2015). Dynamic Relationship between Income and Consumption: A Time Series Analysis of Spain. Developing Country Studies. Vol. 5. No. 1. 2015.

[3] Algahtani, I., Alhiyari, M. (1987). Real Balance Effect and the Consumption Function in LDCs: A comment. The American Economist. Vol. 31. No1. Pp. 62-63.

[4] Arestis, P., Driver, C. (1981). Consumption Out of Different Types of Income in the U.K. (1980). Bulletin of Economic Research. Vol. 32. Pp. 85-96.

[5] Bodkin, R. (1959). Windfall Income and Consumption. American Economic Review. Vol. 49. No. 3-5. Pp. 602-614.

[6] Engle, Robert F., Granger, Clive W. J. (1987). Cointegration and Error Correction: Representation, Estimation and Testing. Econometrica. 55 (2). 251-76.

[7] Fortune, J. (1982). Expected Inflation, Wealth Effects and Personal Expenditure. Weltwirt. Archives. Vol. 118. Pp. 205-213.

[8] Genchev, E. P. (2012). Analysis of Income-Consumption relationship in Bulgaria and Russia. Framework for Classification of Information. No. 4. Pp. 115-119.

[9] Gulcin, T., Aycan, H. (2014). An Analysis of Household Consumption Expenditure in EA-18. European Scientific Journal. Vol. 10. No. 16. June 2014.

[10] Howard, D. (1978). Personal Saving Behavior and the Rate of Inflation. The Review of Economics and Statistics. Vol. 60. Pp. 547-554.

[11] Johansen, S., Juselius, K. (1990). Maximum likelihood Estimation and Inference on Cointegration with Application to the Demand for Money. Oxford Bulletin of Economics and Statistics. Vol. 52, No. 2, Pp.169-210.

[12] Khan, A., Azam, M., Ejaz, M. (2014). Analysis of Consumption Behavior Concerning Current Income and Lags Consumption: Empirical Evidence from Pakistan. Ekonomski Vjesnik/Econviews. Pp. 59-70. March, 2014.

[13] Khatkhate, D., Bhatia, R. (1975). Financial Intermediation, Savings Mobilization, and Entrepreneurial Development: The African Experience. IMF Staff Papers. Vol. 22. Pp. 132-158.

[14] Koskela, E., Viren, M. (1985). On the Role of Inflation in Consumption Function. Weltwirt. Archives. Vol. 121. Pp. 252260.

[15] Mehdizadeh, M. (1985). The Effect of Liquid Assets on the Consumption Function of Less Developed Economy.: A note. The American Economist. Vol. 29. No. 1. Pp. 78-79.

[16] Suits, D. The Determinants of Consumer Expenditure: A review of Present Knowledge. In Johnson, W., Kamerschen, D. (Eds.). Macroeconomics. Selected Readings. Houghton Miffin Company. 1970.

[17] Thankgod, A. (2014). Private Consumption Expenditure Function in Nigeria: Evidence from the Keynes' Absolute Income Hypothesis. International Journal of Research in Social Sciences. Vol. 4. No. 3. July 2014. 
274 Abdulaziz Hamad Algaeed: Money Supply as a Conduit of the Consumption in the Saudi Economy: A Co-integration Approach

[18] The Saudi Arabian Monetary Agency (SAMA) annual Report. Various Issues.

[19] Wadad, S. (2011). An econometric Study of the Private Consumption Function in Lebanon. International Research Journal of Economics and Finance. Issue, 61. 2011.
[20] Yuan, M. (2012). Is Consumption in the United States Influenced by Income Inequalities? Political Economy. Vol. 21. Pp. 31-45. 2012. 